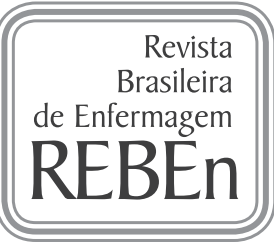

RESEARCH

\title{
Terms of the specialized nursing language for the care of ostomates
}

\author{
Termos da linguagem especializada de enfermagem para o cuidado à pessoa ostomizada \\ Términos de lenguaje específico de enfermería para el paciente de ostomía
}

\section{Carina Maris Gaspar Carvalho', Marcia Regina Cubas", Maria Miriam Lima da Nóbrega'}

' Universidade Federal da Paraíba, Postgraduate Program in Nursing. João Pessoa, Paraíba, Brazil. "Pontifícia Universidade Católica do Paraná, Postgraduate Program in Health Technology. Curitiba, Paraná, Brazil.

How to cite this article:

Carvalho CMG, Cubas MR, Nóbrega MML. Terms of the specialized nursing language for the care of ostomates. Rev Bras Enferm [Internet]. 2017;70(3):461-7. DOI: http://dx.doi.org/10.1590/0034-7167-2015-0058

Submission: 12-30-2015 Approval: 09-19-2016

\begin{abstract}
Objectives: to identify terms of the specialized nursing language for the care of ostomates from the literature of the area, and to map the identified terms with terms of the International Classification for Nursing Practice (ICNP). Method: descriptive study of quantitative approach guided by the guidelines for the elaboration of terminology subsets of the ICNP ${ }^{\circledR}$. The terms were collected in 49 scientific articles, extracted using a computational tool, selected according to the relevance for the theme, and normalized and mapped with the ICNP ${ }^{\circledast}$. Results: 20,668 terms were extracted. The standardization process resulted in 425 relevant terms (151 were constant in ICNP and 274 were not contained in ICNP ${ }^{\otimes}$, of which 154 were similar, 19 were more comprehensive, 50 were more restricted, and 51 were not in concordance. Conclusion: the use of standardized language can minimize the ambiguities and redundancies identified in the mapping. The existence of terms not in concordance with the ICNP ${ }^{\circledast}$ reinforces the need for constant updating of this classification. Descriptors: Nursing; Classification; Terminology; Nursing Processes; Ostomy.
\end{abstract}

\section{RESUMO}

Objetivos: identificar termos da linguagem especializada de enfermagem para o cuidado à pessoa ostomizada, a partir da literatura da área; e mapear os termos identificados com termos da Classificação Internacional para a Prática de Enfermagem $\left(\mathrm{CIPE}^{\circledR}\right)$. Método: pesquisa descritiva, de abordagem quantitativa, orientada pelas diretrizes para a elaboração de subconjuntos terminológicos da CIPE ${ }^{\circledast}$. Os termos foram coletados em 49 artigos científicos, extraídos com uso de ferramenta computacional,

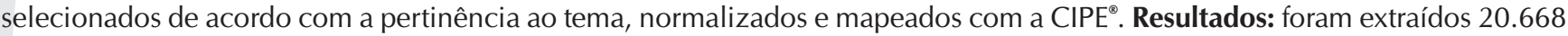
termos. A normalização resultou em 425 termos pertinentes, sendo: 151 termos constantes e 274 não constantes na CIPE ${ }^{\circledR}$; dos quais 154 similares, 19 mais abrangentes, 50 mais restritos e 51 sem concordância. Conclusão: o uso de linguagem padronizada pode minimizar ambiguidades e redundâncias identificadas no mapeamento. A existência de termos sem concordância com a $\mathrm{CIPE}^{\circledast}$ reforça a necessidade de atualização constante dessa classificação.

Descritores: Enfermagem; Classificação; Terminologia; Processos de Enfermagem; Estomia.

\section{RESUMEN}

Objetivos: identificar los términos del lenguaje especializado de atención de enfermería para el paciente de ostomía a partir de la literatura de la zona y hacer el mapeo de los términos identificados con los términos de la Clasificación Internacional para la Práctica de Enfermería (ICNP ${ }^{\circledR}$ ). Método: estudio descriptivo, enfoque cuantitativo, guiado por las directrices para la preparación de subconjuntos de terminología de ICNP ${ }^{\circledR}$. Los términos se recogieron en 49 artículos científicos con el uso de la herramienta informática, fueron seleccionados en función de la relevancia del tema, fueron normalizados y hecho el mapeo con términos de ICNP. Resultados: 20.668 términos fueron extraídos. La normalización resultó en 425 términos relevantes, como sigue: 151 términos contenidos y 274 no contenidos en ICNP; 154 de los cuales similares, 19 más amplios, 50 más limitados y 51 sin acuerdo. Conclusión: el uso de un 
lenguaje estandarizado puede reducir al mínimo las ambigüedades y las redundancias identificadas en el mapeo. La existencia de términos sin acuerdo con el ICNP ${ }^{\circledast}$ refuerza la necesidad de una actualización constante de esta clasificación.

Descriptores: Enfermería; Clasificación; Terminología; Procesos de Enfermería; Estoma.

\section{CORRESPONDING AUTHORＣarina Maris Gaspar Carvalho＿E-mail: carina.mgcarvalho@gmail.com}

\section{INTRODUCTION}

A stoma is a visceral opening through the skin performed through a surgical act with the purpose of promoting breathing, feeding or elimination ${ }^{(1)}$. An intestinal elimination stoma involves the exteriorization of a portion of the intestine, and is indicated when a part of the small or large intestine is unable, temporarily or permanently, to perform its functions. Therefore, it has the purpose of allowing the elimination of faeces through the abdominal wall. An intestinal elimination stoma is a colostomy (when there is exteriorization of a portion of the colon, large intestine) or an ileostomy (when there is exteriorization of a portion of the ileum, small intestine) $)^{(2)}$.

A surgery generating a stoma may be needed at any stage of life for several reasons ${ }^{(3)}$, and people undergoing this surgery are called 'ostomates'(1). Considering that stoma in children have peculiar characteristics requiring specific attention ${ }^{(3)}$, the present study will be limited to adults with intestinal elimination stomas, denominating them as ostomates.

Ostomates have their anatomy and physiological functions altered, and can present psychosocial changes ${ }^{(4)}$. Therefore, health care for ostomates requires specialized interdisciplinary interventions ${ }^{(1)}$. Nursing plays an important role in the rehabilitation process, which is achieved by minimizing the biopsychosocial consequences of a stoma(5).

Considering the need to systematize nursing care to ostomates ${ }^{(6-7)}$, the importance of using nursing terminologies stands out, since they allow the identification and documentation of care standards ${ }^{(8)}$. The International Classification for Nursing Practice $\left(\right.$ ICNP $\left.^{\circledR}\right)$ is a standardized terminology of the nursing language. Its structure of terms and definitions allows the collection, description and systematic documentation of nursing practice elements - what nurses do (nursing interventions) in relation to certain human needs (nursing diagnoses) to produce results (nursing outcomes) ${ }^{(9)}$.

The ICNP ${ }^{\circledast}$ has been constantly updated to improve its structure and facilitate its use by nurses. Since its first version, the Alpha of 1996, eight updates have been made available, and the 2015 version is the most recent ${ }^{(9)}$.

Atomic terms are the primitive concepts included in the seven ICNP ${ }^{\otimes}$ - Focus, Judgment, Means, Action, Client, Location and Time. Molecular terms are pre-coordinated concepts that refer to statements of diagnoses, outcomes and nursing interventions resulting from terminological subsets ${ }^{(10)}$.

The ICNP ${ }^{\circledast}$ terminology subsets are sets of statements of diagnoses, outcomes and nursing interventions directed to a specific clientele, health priority or nursing phenomenon. To support the development of a terminology subset of ICNP the International Council of Nurses (ICN) has developed a guideline with ten steps $^{(11)}$. In light of methodological studies to develop subsets, Brazilian researchers proposed a method consisting of four steps ${ }^{(12)}$ : 1) identification of relevant terms for the clientele and/or the health priority; 2) cross-mapping of the identified terms with ICNP ${ }^{\circledast}$ terms; 3) elaboration of nursing diagnosis, outcomes and interventions; and 4) structuring of the ICNP ${ }^{\circledast}$ terminology subset.

The present study is the first phase of an ongoing research that will develop a terminology subset of ICNP ${ }^{\circledast}$ for the care of people with intestinal elimination stomas. As the identification of relevant terms can occur from the literature, official documents, patients' records, area-specific database or the $\mathrm{ICNP}^{\circledast}$ itself $^{(12)}$, the objectives of this article were to identify terms of the specialized nursing language for the care of ostomates from the literature of this area; and map the identified terms with ICNP ${ }^{\circledast}$ terms.

\section{METHOD}

\section{Ethical aspects}

This study is a part from an ongoing research entitled "ICNP ${ }^{\circledast}$ terminology subset structured in ontology for the care of people with intestinal elimination stomas". It was approved by the Research Ethics Committee of the Lauro Wanderley University Hospital of the Universidade Federal da Paraíba.

\section{Study design, location and period}

A descriptive study of quantitative approach guided by the first and second steps of the guidelines for elaboration of ICNP ${ }^{\circledast}$ terminology subsets ${ }^{(12)}$.

This is a bibliographical research, and the data collection period was from May to July 2015.

\section{Research universe and sample}

The research universe were the scientific publications on nursing care for people with intestinal elimination stomas. The sample included articles of journals indexed in databases of (SciELO), Latin American and Caribbean Literature in Health Sciences (LILACS) and Nursing Database (BDENF). Note that the search was not extended to other health databases because of the intentional choice of selecting publications in Portuguese to extract terms only in this language because the cross-mapping would be with terms of the Portuguese version of ICNP ${ }^{\circledR}$. The keywords for database search were: "estomia and enfermagem", "estoma and enfermagem", "ostomia and enfermagem", "colostomia and enfermagem" and "ileostomia and enfermagem".

The criteria for selecting articles in the databases were: articles published between 2004 and 2015; Portuguese language; and title or abstract suggestive of nursing care for people with intestinal elimination stomas. Articles not available in full, those related to stoma in children and those repeated in the databases were excluded. 


\section{Study protocol}

Sections of low relevance terms such as titles, authors, information about the authors, abstracts, footnotes, methodology, references and acknowledgments were removed of the selected publications. Then, articles were grouped into a single Word ${ }^{\circledast}$ file, which was converted into portable document format (PDF).

The extraction of terms occurred with use of the Poronto tool $^{(13)}$ to process the PDF file, which resulted in a list of terms organized in order of occurrence in an Excel $^{\circledR}$ worksheet. Among the extracted terms, nouns, adjectives and verbs were selected based on frequency of appearance and relevance to the research theme. Then, the selected terms were submitted to a standardization process of gender and verbal inflections, number and degree of nouns and adjectives, with the purpose to identify and remove repeated terms. The selection of articles and normalization of terms were performed by an independent researcher.

Then, the normalized terms were cross-mapped with terms of the ICNP ${ }^{\oplus}$ version 2013 that includes 3,894 terms, of which 2,302 atomic terms and 1,592 molecular terms ${ }^{(14)}$. The 2013 version was used because it was the last version available in Portuguese at the moment of the mapping process.

The Access ${ }^{\oplus}$ tool was used for the mapping, resulting in an Excel $^{\circledR}$ spreadsheet with terms contained in ICNP ${ }^{\curvearrowleft}$ and terms not constant in ICNP.

\section{Analysis of results}

The non-constant terms were subjected to an analysis process of similarity and comprehensiveness in relation to ICNP ${ }^{\circledast}$ terms according to the following criteria ${ }^{(15)}$ : the term is considered similar when there is no agreement of spelling, but its meaning is identical to the existing ICNP ${ }^{\circledast}$ term; the term is considered more comprehensive when its meaning is broader than the existing ICNP ${ }^{\oplus}$ term; the term is considered more restricted when it has a more specific meaning than the existing ICNP ${ }^{\circledast}$ term; and the term is not in concordance when it is totally different from existing ICNP ${ }^{\circledR}$ terms.

The meaning of each ICNP ${ }^{\circledR}$ term was represented by its respective definition. Since some terms identified in the literature are not accompanied by their definitions, their meanings were taken from constant meanings in dictionaries of the Portuguese language and based on authors' prior knowledge. The mapping and analysis of similarity and comprehensiveness were performed by an independent researcher and analyzed by two other independent researchers. Divergences found were discussed between the three researchers, and the result was decided by consensus.

\section{RESULTS}

The extraction of terms for the care of ostomates in the 49 selected articles resulted in 20,668 terms. The process of selecting and normalizing the extracted terms resulted in a list of 425 relevant terms, of which 277 nouns, 29 adjectives and 119 verbs. Chart 1 has examples of relevant terms to the care of ostomates identified in the literature.
Chart 1 - Examples of relevant terms for the care to ostomates identified in 49 articles published between 2004 and 2015 in the SciELO, LILACS and BDENF databases, presented by frequency of appearance (n) and categorized by nouns, adjectives and verbs, 2015

\begin{tabular}{|l|c|l|c|l|c|}
\hline \multicolumn{1}{|c|}{ Nouns } & $(\mathbf{n})$ & Adjectives & (n) & \multicolumn{1}{c|}{ Verbs } & (n) \\
\hline Care & 879 & Ostomates & 591 & Performing & 253 \\
\hline Patient & 769 & Intestinal & 401 & Caring & 192 \\
\hline Health & 655 & Ostomates & 147 & Fazer & 174 \\
\hline Professional & 620 & Social & 135 & Talking & 105 \\
\hline Ostomy & 520 & Psychological & 96 & Observing & 76 \\
\hline Stoma & 484 & Emotional & 96 & Promoting & 73 \\
\hline Person & 482 & Bodily & 95 & Helping & 71 \\
\hline Nurse & 448 & Temporary & 86 & Evaluating & 60 \\
\hline Familiar & 414 & Adequate & 84 & Guiding & 56 \\
\hline Bag & 387 & Sexual & 74 & Offering & 53 \\
\hline Colostomy & 340 & Definitive & 70 & Changing & 52 \\
\hline Family & 333 & Present & 48 & Putting & 49 \\
\hline Self-care & 267 & Permanent & 47 & Washing & 38 \\
\hline Rehabilitation & 147 & Spiritual & 19 & Explaining & 32 \\
\hline Complication & 126 & Peristomal & 14 & Teaching & 31 \\
\hline Ileostomy & 70 & Provisional & 8 & Preventing & 16 \\
\hline Adjuvant & 33 & Absent & 6 & Encouraging & 15 \\
\hline Stoma & 31 & Impaired & 5 & Documenting & 5 \\
\hline Stoma & 19 & Transparent & 5 & Hygiening & 5 \\
\hline Gas & 7 & Opaque & 1 & Reporting & 2 \\
\hline
\end{tabular}

The cross-mapping of the 425 terms identified in the literature and terms of the ICNP ${ }^{\circledR}$ version 2013 resulted in 151 constant terms and 274 terms not contained in ICNP ${ }^{\oplus}$. Of these, 154 were classified as similar, 19 as more comprehensive, 50 as more restricted, and 51 were not in concordance with the ICNP ${ }^{\circledast}$ terms.

The following are examples of terms identified in the literature and contained in ICNP": "Patient", "Health", "Stoma", "Ostomy", "Colostomy", "Nurse", "Ileostomy", "Family", "Selfcare", "Body", "Adaptation", "Complication", "Skin", "Faeces", "Intestine", "Self-esteem", "Socialization", "Oedema", "Flatus (gas)", "Present", "Impaired", "Talking", "Observing", "Promoting", "Evaluating", "Guiding", "Offering", "Changing", "Washing", "Explaining", "Preventing", and "Documenting".

Chart 2 has examples of terms that are similar to ICNP ${ }^{\circledR}$ terms.

Chart 3 has examples of more comprehensive terms and more restrictive terms in relation to ICNP ${ }^{\circledR}$ terms.

The following are examples of terms identified in the literature that are not in concordance with ICNP ${ }^{\circledast}$ terms: "change", "adjuvant ", "powder", "paste", "belt", "temporary", "definitive", "transparent" and "opaque". 
Chart 2 - Examples of nursing language terms for the care of ostomates not conatined in ICNP ${ }^{\circledR}$, classified as similar to the terms of the ICNP ${ }^{\circledR}$

\begin{tabular}{|l|l|}
\hline \multicolumn{1}{|c|}{ Identified term } & \multicolumn{1}{c|}{ ICNP ${ }^{\circledR}$ corresponding term } \\
\hline Stomata & Stoma \\
\hline Bag & Colostomy bag/lleostomy bag \\
\hline Person & Individual \\
\hline Familiar & Family \\
\hline Feeling & Emotion \\
\hline Rehabilitation & Rehabilitation regime \\
\hline Effluent & Faeces \\
\hline Realizing & Performing \\
\hline Making & Performing \\
\hline Helping & Assisting \\
\hline Fazer & Executar \\
\hline Ajudar & Auxiliar \\
\hline
\end{tabular}

Chart 3 - Examples of nursing language terms for the care of ostomates not contained in ICNP ${ }^{\circledR}$, classified as more comprehensive and more restricted in relation to ICNP ${ }^{\circledR}$ terms

\begin{tabular}{|l|l|c|}
\hline Identified term & $\begin{array}{c}\text { ICNP® } \\
\text { corresponding term }\end{array}$ & $\begin{array}{c}\text { Analysis of the } \\
\text { identified term }\end{array}$ \\
\hline Image & Body image & More comprehensive \\
\hline Isolation & Social isolation & More comprehensive \\
\hline Smell & Foul odour & More comprehensive \\
\hline Odour & Foul odour & More comprehensive \\
\hline Right & Patient right & More comprehensive \\
\hline Prolapse & Stoma complication & More restricted \\
\hline Retraction & Stoma complication & More restricted \\
\hline Undermining & Stoma complication & More restricted \\
\hline Dermatitis & Inflammation & More restricted \\
\hline Reporting & Documenting & More restricted \\
\hline
\end{tabular}

\section{DISCUSSION}

In the literature selected by this study, the terms "ostomy", "stomata", and "stoma" are used to designate the exteriorization of part of the intestine through the abdomen for faeces elimination. The ICNP 2013 includes the terms "stoma" and "ostomy", but with different meanings - "stoma" is defined as "Body Opening"(14) and "ostomy" is defined as "Surgery"(14). These terms are also inserted in different axes of the ICNP ${ }^{\circledR}$ "stoma" is in Location and "ostomy" in Means.
The term "stoma" is the translation of the greek term stóma that means "mouth"(16-19). The dictionary search for the meanings of the terms "stoma" and "ostomy" shows variations, and "stomata" is the plural of "stoma"(17-18). Dictionaries can also present "stomata" as synonymous with "stoma", defined as stóma ${ }^{(19)}$. Due to uncertainties about the most suitable term for naming the intestine part externalized through the abdominal wall, the Brazilian Stomatherapy Association (SOBEST), after consulting the Brazilian Academy of Letters, has been using the term "stoma" since $2004^{(20)}$. However, the results of this study demonstrate that different terms are still used to express the same meaning.

Considering the stoma as a body opening that replaces the function of the anus, the terms identified in the literature were classified as similar to "stoma" in ICNP". The term "ostomy" was maintained as constant in ICNP ${ }^{\circledR}$, hence assuming the definition of the classification. However, due to the synonymy between terms, "ostomy" could be classified as similar to "stoma". Despite the efforts of both SOBEST and ICNP ${ }^{\circledast}$ to standardize a term for "stoma", there is still no consensus among nurses, given the literature analyzed. In order to standardize the term in this study and use the language standard offered by the ICNP", we chose "stoma".

Rehabilitation is the main goal to be achieved in the health care of ostomates ${ }^{(1)}$. The term "rehabilitation" was identified in the literature and classified as similar to the term "Rehabilitation Regime" of ICNP ${ }^{\circledast}$, included in the Focus axis. The process of rehabilitation of people undergoing surgeries creating a stoma should aim at encouraging self-care with the stoma and peristomal skin to promote their physical independence and social reintegration ${ }^{(21-22)}$. Thus, self-care has significant relevance in the context of care of ostomates. The term "self-care" is included in the Focus axis of ICNP ${ }^{\circledast}$ and is defined by the classification as "Self performing activity: taking care of what is needed to maintain oneself, keep oneself going and handle basic individual and intimate necessities and activities in daily life ${ }^{\prime \prime(14)}$. In the aspect of health and social care, self-care is an essential component. Without it, social and health systems would collapse, since self-care provides the means to reduce excessive hospital admissions, length of stay in outpatient clinics/wards and, consequently, hospitalization expenses ${ }^{(23)}$.

In addition to assistance from the health team, family support to ostomates is essential for accepting the stoma and consequently, the rehabilitation and adaptation to the new life condition ${ }^{(24)}$. The terms "familiar" and "family" were identified in the literature, highlighting the important role of family in the rehabilitation of ostomates, either as an agent that facilitates (in the sense of support) or makes it difficult (in the sense of denial). The term "family" is included in ICNP ${ }^{\circledast}$ in the Client axis, and the term "familiar" has been classified as similar to "family".

Another term identified in the literature that deserves attention is "bag". In the field of nursing practice directed to ostomates, "bag" refers to the stool collection bag because faeces elimination of ostomates occurs involuntarily by the externalized intestine in the abdomen skin, leading to the need for collection bags ${ }^{(25)}$. The term "bag", generally, does not appear in ICNP ${ }^{\circledast}$, but was classified as similar to the specific terms "colostomy bag" and "ileostomy bag" of the classification. Both are included in the Means axis, considering that the 
same bag used to collect stool from a colostomy can be used for collection of an ileostomy.

In the scope of rehabilitation of ostomates, the prevention of complications in the stoma and the peristomal skin is of fundamental importance ${ }^{(1)}$. The term "complication" was identified in the literature and is included in the ICNP ${ }^{\circledast}$ in the Focus axis. The classification also includes the term "stoma complication" in the Focus axis. In the literature, were identified terms referring to ostomy complications - "prolapse", "retraction", "undermining" and "ischemia" - and terms referring to peristomal skin complications - "dermatitis" and "oedema". Among these, only "oedema" appears in ICNP ${ }^{\circledast}$ in the Focus axis, but "prolapse", "retraction", "undermining" and "ischemia" were classified as more restricted in relation to the term "stoma complication" of the Classification. However, the term "dermatitis" was classified as more restricted in relation to the term "inflammation", which is listed in the Focus axis of ICNP", because peristomal dermatitis is an inflammation resulting from contact with faeces or irritating products to the peristomal skin.

To avoid complications in the stoma and peristomal skin, it may be necessary to use protection and safety adjuvants ${ }^{(1)}$. Among the adjuvants identified in the literature are "powder", "paste" and "belt". These terms are not included in ICNP ${ }^{\otimes}$ and were classified as not in concordance with the classification terms because they are specific concepts of a specific domain of nursing practice and do not corroborate any definition of any ICNP ${ }^{\circledast}$ term.

It is important to discuss that the selected literature has essential terms for caring for ostomates, despite their low frequency. For example, the term "gases" appears in the ICNP as "flatus (Gases)" in the Focus axis. As ostomates have no control over their gas elimination ${ }^{(25)}$, there may be embarrassment due to possible noises and bad smell, which may lead to social isolation ${ }^{(26)}$. This fact reinforces the need for guidance from nurses regarding measures that minimize or avoid these situations.

Among the adjectives identified in the literature on care for ostomates, there are terms used as generic qualifiers, that is, they can be applied to different situations within the context of nursing practice (for example, "present", "absent", "adequate" and "impaired"), and terms for specific situations (such as in the period of permanence of the stoma - "temporary", "definitive", "provisional" and "permanent"; and the characteristic of the collection bag - "transparent" and "opaque"). Of these, only "present" and "impaired" are included in the ICNP ${ }^{\circledR}$ in the Time and Judgment axis, respectively. Note that ICNP ${ }^{\circledast}$ includes the term "presence or absence" in the Judgement axis, which leads to classifying the term "absent" as more restricted in relation to "presence or absence". The term "adequate", in turn, was classified as more restricted in relation to "positive or negative judgment" of ICNP ${ }^{\circledast}$, also included in the Judgment axis.

Also regarding the adjectives, were identified terms that demonstrate the concern of publications in covering the social, psychological, sexual and spiritual aspects of ostomates. The identified adjectives "social", "psychological", "sexual", and "spiritual" do not appear in ICNP ${ }^{\circledast}$. However, the classification includes terms that make the identified adjectives visible, such as "social process", "psychological process", "sexual process" and "spiritual process" included in the Focus axis. It is important that nurses get involved in actions focused beyond the physical aspects of ostomates ${ }^{(27)}$, because the consequences resulting from physical changes and the possible complications arising from a stoma may lead to biopsychosocial changes ${ }^{(4)}$.

The verbs identified in the literature portray nursing actions related to care, such as "performing", "caring", "doing", "evaluating", "guiding", "changing" and "washing"; and to care management, such as "documenting" and "reporting". Of these, "evaluating", "guiding", "changing", "washing" and "documenting" are included in the ICNP ${ }^{\circledR}$ Action axis. Based on the verbs identified, the actions aimed at the practice itself predominate over the actions aimed at documentation of nursing practice, which reinforces the need to use nursing terminologies.

\section{Limitations of the study}

As the search for terms has been restricted to the literature of the area, the present study may not reveal the complexity of care in the environments of care practice to people with intestinal elimination stomas, which characterizes a study limitation.

\section{Contributions to the nursing area}

As implications for practice, this study can contribute to the standardization of the nursing language in the context of care for ostomates, which may support the documentation and, consequently, lead to the profession visibility.

\section{CONCLUSION}

Although the literature uses different terms to designate the exteriorization of part of the intestine through the abdomen for the elimination of faeces, the ICNP ${ }^{\circledR}$ differentiates the terms "stoma" and "ostomy". Thus, the use of standardized language can minimize the ambiguities and redundancies related to ostomies.

The identification of terms in the literature allows to conclude there are terms with low frequency of appearance, but essential for the nursing practice directed to ostomates. The mapping showed that despite the specific terms of the specialty in the $\mathrm{ICNP}^{\circledast}$, there are relevant terms not represented in the classification, reinforcing the need for constant updating of the ICNP ${ }^{\circledR}$.

The limitation of the study is the restriction of search for terms to the literature of the area, which may not reveal the complexity of care in the environments of care practice to people with intestinal elimination stomas.

As suggestion for further research after the construction of the terminology subset of ICNP ${ }^{\circledast}$ for the care of ostomates, is the clinical validation of this subset to support evidence for the practice.

\section{FUNDING}

Research funded by the Conselho Nacional de Desenvolvimento Científico e Tecnológico (CNPq) under process number 448448/2014-9.

Scholarship of the Social Demand Program (Programa de Demanda Social - DS) of the Coordenação de Aperfeiçoamento de Pessoal de Nível Superior (CAPES). 


\section{REFERENCES}

1. Brasil. Ministério da Saúde. Portaria nº . 400, de 16 de novembro de 2009. Diretrizes nacionais para a atenção à saúde das pessoas ostomizadas no âmbito do Sistema Único de Saúde - SUS [Internet]. Diário Oficial da União 18 de nov 2009 [cited 2016 Aug 19];Seção I. Available from: http://bvsms.saude.gov.br/bvs/saudelegis/sas/2009/prt0400_16_11_2009.html

2. Hendren S, Hammond K, Glasgow SC, Perry WB, Buie WD, Steele SR, Rafferty J. Clinical practice guidelines for ostomy surgery. Dis Colon Rectum [Internet]. 2015 [cited 2016 Aug 19];58(4):375-87. Available from: https://www.fascrs.org/sites/default/files/ downloads/publication/clinical_practice_guidelines_for_ostomy_surgery.pdf

3. Poletto D, Gonçalves MI, Barros MTT, Anders JC, Martins ML. A criança com estoma intestinal e sua família: implicações para o cuidado de enfermagem. Texto Contexto Enferm [Internet]. 2011 [cited 2016 Aug 19]; 20(2):319-27. Available from: http://www. scielo.br/pdf/tce/v20n2/a14v20n2.pdf

4. Martins PAF, Alvim NAT. Saberes e práticas de clientes estomizados sobre a manutenção da estomia de eliminação intestinal e urinária e sua pertinência no cuidado. Perspect Online Biol Saúde [Internet]. 2012 [cited 2016 Aug 19];6(2):54-69. Available from: http://www.seer.perspectivasonline.com.br/index.php/biologicas_e_saude/article/view/210/127

5. Coelho AR, Santos FS, Poggetto MTD. A estomia mudando a vida: enfrentar para viver. REME Rev Min Enferm [Internet]. 2013 [cited 2016 Aug 19];17(2):268-77. Available from: www.reme.org.br/exportar-pdf/649/v17n2a03.pdf

6. Ardigo FS, Amante LN. Knowledge of the professional about nursing care of people with ostomies and their families. Text Context Nursing [Internet]. 2013 [cited 2016 Aug 19];22(4):1064-71. Available from: http://www.scielo.br/pdf/tce/v22n4/en_24.pdf

7. Ramos RS, Barros MD, Santos MM, Gawryszewiski ARB, Gomes AMT. O perfil dos pacientes estomizados com diagnóstico primário de câncer de reto em acompanhamento em programa de reabilitação. Cad Saúde Colet [Internet]. 2012 [cited 2016 Aug 19];(3):280-6. Available from: http://www.iesc.ufrj.br/cadernos/images/csc/2012_3/artigos/CSC_v20n3_280-286.pdf

8. Nóbrega MML, Garcia TR. Perspectivas de incorporação da Classificação Internacional para a Prática de Enfermagem (CIPE) no Brasil. Rev Bras Enferm [Internet]. 2005 [cited 2016 Aug 19];58(2):227-30. Available from: http://www.scielo.br/pdf/reben/v58n2/a20.pdf

9. Garcia TR (Org.). Classificação Internacional para a Prática de Enfermagem CIPE : versão 2015. Porto Alegre: Artmed; 2016.

10. Garcia TR, Nóbrega MML. A terminologia CIPE $^{\oplus}$ e a participação do Centro CIPE $^{\circledast}$ brasileiro em seu desenvolvimento e disseminação. Rev Bras Enferm [Internet]. 2013 [cited 2016 Aug 19];66(esp):142-50. Available from: http://www.scielo.br/pdf/ reben/v66nspe/v66nspea18.pdf

11. International Council of Nurses. Guidelines for ICNP ${ }^{\circledast}$ catalogue development [Internet]. Genebra: International Council of Nurses; 2008 [cited 2016 Aug 19]. Available from: http://www.icn.ch/images/stories/documents/programs/icnp/icnp_catalogue development.pdf

12. Nóbrega MML, Cubas MR, Egry EY, Nogueira LGF, Carvalho CMG, Albuquerque LM. Desenvolvimento de subconjuntos terminológicos da CIPE no Brasil. In: Cubas, MR. Nóbrega, MM.L. (Org.). Atenção Primária em Saúde: diagnósticos, resultados e intervenções. Rio de Janeiro: Elsevier; 2015. p. 3-8.

13. Zahra FM, Carvalho DR, Malucelli A. Poronto: ferramenta para construção semiautomática de ontologias em português. J. Health Inform [Internet]. 2013 [cited 2016 Aug 19];5(2):52-9. Available from: http://www.jhi-sbis.saude.ws/ojs-jhi/index.php/jhi-sbis/ article/view/232/167

14. Garcia TR. CIPE Versão 2013. In: Garcia, TR. (Org.). Classificação Internacional para a Prática de Enfermagem CIPE: Aplicação à realidade brasileira. Porto Alegre: Artmed; 2015. p. 123-299.

15. Leal MT. A CIPE e a visibilidade da enfermagem: mitos e realidade. Lisboa: Lusociência; 2006.

16. Bacelar S, Galvão CC, Alves E, Tubino P. Expressões médicas errôneas: erros e acertos. Acta Cir Bras [Internet]. 2004 [cited 2016 Aug 19];19(5):582-4. Available from: http://www.scielo.br/pdf/acb/v19n5/a19v19n5.pdf

17. Koogan A, Houaiss A. Enciclopédia e Dicionário Koogan Houaiss. Edições Delta. 2009.

18. Michaelis. Dicionário de Português Online [Internet]. Editora Melhoramentos; 2016 [cited 2016 Aug 19]. Available from: http:// michaelis.uol.com.br/.

19. Priberam. Dicionário Priberam da Língua Portuguesa[Internet]. 2013 [cited 2016 Aug 19]. Available from: http://www.priberam. $\mathrm{pt} / \mathrm{dlpo} /$.

20. Yamada BFA. Associação Brasileira de Estomaterapia: estomias, feridas e incontinências - SOBEST [Internet]. Fundação. 2016 [cited 2016 Aug 19]. Available from: http://www.sobest.org.br/texto/3

21. Cesaretti IUR. Cuidando da pessoa com estoma no pós-operatório tardio. Revista Estima [Internet]. 2008 [cited 2016 Aug 19];6(1). Available from: http://www.revistaestima.com.br/index.php/estima/article/view/226

22. Sampaio FAA, Aquino PS, Araújo TL, Galvão MTG. Nursing care to an ostomy patient: application of the Orem's ttheory. Acta Paul Enferm [Internet]. 2008 [cited 2016 Aug 19];21(1):94-100. Available from: http://www.scielo.br/pdf/ape/v21n1/14.pdf

23. Kollak I. The concept of self-care. In: Kim HS, Kollak I, editors. Nursing theories: conceptual and philosophical foundations. 2 ed. 
New York: Springer Publishing Company; 2006.

24. Rodrigues SO, Budó MLD, Simon BS, Gewehr M, Silva DC. As redes sociais de apoio no cuidado às pessoas com estomias: revisão bibliográfica. Rev Saúde (Santa Maria) [Internet]. 2013 [cited 2016 Aug 19];39(1):3342. Available from: http://periodicos. ufsm.br/revistasaude/article/download/7256/pdf_1

25. Rocha JJR. Estomas intestinais (ileostomias e colostomias) e anastomoses intestinais. Medicina (Ribeirão Preto) [Internet]. 2011 [cited 2016 Aug 19];44(1):51-6. Available from: http://www.revistas.usp.br/rmrp/article/view/47335/51071

26. Batista MRFF, Rocha FCV, Silva DMG, Silva Júnior FJG. Autoimagem de clientes com colostomia em relação à bolsa coletora. Rev Bras Enferm [Internet]. 2011 [cited 2016 Aug 19]; 64(6):1043-7. Available from: http://www.scielo.br/pdf/reben/v64n6/v64n6a09.pdf

27. Araújo JBGN, Alencar AMPG. Assistência de enfermagem ao portador de ostomia intestinal na atenção básica. Cad Cult Ciênc [Internet]. 2013 [cited 2016 Aug 19];12(2):78-87. Available from: http://periodicos.urca.br/ojs/index.php/cadernos/article/ view/633/pdf_1 